\title{
QUEEN'S
UNIVERSITY
BELFAST
}

\section{Enhancing the lycopene in vitro bioaccessibility of tomato juice synergistically applying thermal and non-thermal processing technologies}

Jayathunge, K. G. L. R., Stratakos, A. C., Cregenzán-Albertia, O., Grant, I. R., Lyng, J., \& Koidis, A. (2017).

Enhancing the lycopene in vitro bioaccessibility of tomato juice synergistically applying thermal and non-thermal processing technologies. Food Chemistry, 221, 698-705. https://doi.org/10.1016/j.foodchem.2016.11.117

Published in:

Food Chemistry

Document Version:

Peer reviewed version

Queen's University Belfast - Research Portal:

Link to publication record in Queen's University Belfast Research Portal

Publisher rights

(c) 20016 Elsevier Ltd. This manuscript version is made available under the CC-BY-NC-ND 4.0 license

$\mathrm{http}: / /$ creativecommons.org/licenses/by-nc-nd/4.0/which permits unrestricted use, distribution and reproduction in any medium, provided the author and source are cited.

\section{General rights}

Copyright for the publications made accessible via the Queen's University Belfast Research Portal is retained by the author(s) and / or other copyright owners and it is a condition of accessing these publications that users recognise and abide by the legal requirements associated with these rights.

Take down policy

The Research Portal is Queen's institutional repository that provides access to Queen's research output. Every effort has been made to ensure that content in the Research Portal does not infringe any person's rights, or applicable UK laws. If you discover content in the Research Portal that you believe breaches copyright or violates any law, please contact openaccess@qub.ac.uk. 


\section{Accepted Manuscript}

Enhancing The Lycopene In Vitro Bioaccessibility of Tomato Juice Synergistically Applying Thermal and Non-Thermal Processing Technologies

K.G.L.R. Jayathunge, Alexandros Ch. Stratakos, Oliver Cregenzán-Albertia, Irene R. Grant, James Lyng, Anastasios Koidis

PII: $\quad$ S0308-8146(16)31966-5

DOI: http://dx.doi.org/10.1016/j.foodchem.2016.11.117

Reference: FOCH 20250

To appear in:

Food Chemistry

Received Date:

1 July 2016

Revised Date:

18 November 2016

Accepted Date:

22 November 2016

Please cite this article as: Jayathunge, K.G.L.R., Stratakos, A.C., Cregenzán-Albertia, O., Grant, I.R., Lyng, J., Koidis, A., Enhancing The Lycopene In Vitro Bioaccessibility of Tomato Juice Synergistically Applying Thermal and Non-Thermal Processing Technologies, Food Chemistry (2016), doi: http://dx.doi.org/10.1016/j.foodchem. 2016.11.117

This is a PDF file of an unedited manuscript that has been accepted for publication. As a service to our customers we are providing this early version of the manuscript. The manuscript will undergo copyediting, typesetting, and review of the resulting proof before it is published in its final form. Please note that during the production process errors may be discovered which could affect the content, and all legal disclaimers that apply to the journal pertain. 


\section{ENHANCING THE LYCOPENE IN VITRO BIOACCESSIBILITY OF TOMATO JUICE SYNERGISTICALLY APPLYING THERMAL AND NON-THERMAL PROCESSING TECHNOLOGIES}

K.G.L.R. Jayathunge ${ }^{\mathrm{a}}$, Alexandros Ch. Stratakos ${ }^{\mathrm{a}}$, Oliver Cregenzán-Albertia ${ }^{\mathrm{b}}$, Irene R. Grant ${ }^{\mathrm{a}}$, James Lyng ${ }^{\mathrm{b}}$, Anastasios Koidis ${ }^{\mathrm{a}}$

a Institute for Global Food Security, Queen's University Belfast, Belfast, Northern Ireland, UK.

${ }^{\mathrm{b}}$ School of Agriculture and Food Science, University College Dublin, Ireland.

Corresponding author:

Dr Anastasios (Tassos) Koidis, Institute for Global Food Security, Queen's University Belfast, 18-30 Malone Road, Belfast, BT9 5BN, Northern Ireland, UK, Tel: +44 2890975569 email: t.koidis@qub.ac.uk 


\section{ABSTRACT}

The influence of moderate intensity pulsed electric field pre-processing on increasing the lycopene bioaccessibility of tomato fruit, and the combined effect of blanching, ultrasonic and high intensity pulsed electric field processing on further enhancement of the lycopene bioaccessibility after juicing were investigated. Maximum total lycopene bioaccessibility $(9.6 \%)$ of the tomato fruit was achieved by a $4 \mu$ s pre-processed treatment after $24 \mathrm{~h}$ holding period and further processing results revealed that all treatments were effective to increase the total lycopene. Most of juice processing treatments decreased the release of lycopene from the tomato matrix during digestion. Only the treatment of blanching followed by high intensity pulsed electric field showed a significant release of trans- $(4.01 \pm 0.48)$ and cis- $(5.04 \pm 0.26 \mu \mathrm{g} / \mathrm{g})$ lycopene, achieving $15.6 \%$ total lycopene bioaccessibility. Thus, processing of pre-blanched juice using high intensity pulsed electric field, derived from pre-processed tomato was the best overall process to achieve the highest nutritive value.

Key words; Tomato; juice; blanching; lycopene; in vitro bioaccessibility; pulsed electric fields; ultrasonic; processing 


\section{INTRODUCTION}

Sufficient uptake of lycopene from the diet is necessary to benefit from its health promoting effects, since humans are unable to synthesise lycopene de novo. Low lycopene bioaccessibility/bioavailability is an identified worldwide issue; therefore there is a focused interest in ways of increasing the uptake of lycopene from the human diet. One of the ways to do this is through a diet rich in tomato juice. It is a real challenge to develop processing conditions during tomato juice production that can result in maximum overall lycopene bioaccessibility.

Different non-thermal processing technologies have emerged in the last few decades to fulfil the consumer desire for highly nutritious "fresh-like" tomato juice products that could potentially replace traditional thermal processing. Among them, pulsed electric fields (PEF) and ultrasonication (US) techniques have been widely investigated (Adekunte, Tiwari, Scannell, \& O’Donnel, 2010; Mosqueda-Melgar, Raybaudi-Massilia, \& Martín-Belloso, 2012; Nguyen and Mittal, 2007; Odriozola-Serrano, Aguilo-Aguayo, Soliva-Fortuny, Gimeno-Ario, \& MartínBelloso, 2007; Odriozola-Serrano, Solivia-Fortuny, Hernandez-Jover, \& Martin-Belloso, 2009). Most non-thermal processing studies have focused on the retention of lycopene content after processing, which is not necessarily representative of its biological value because it is not indicative of how much is bioavailable after ingestion (Krebbers, Matser, Hoogerwerf, Morzelaar, Momassen, \& Van den berg, 2003; Odriozola-Serrano et al., 2007). In most of these studies, the impact of PEF and US processing on lycopene bioaccessibility of tomato juice has not been well characterised. Anese, Mirolo, Beraldo \& Lippe (2013) studied the effect of ultrasonic treatments on the microstructure of tomato pulp and lycopene in vitro bioaccessibility and observed a more than three-fold reduction in lycopene bioaccessibility after ultrasonication. No systematic studies, neither in vivo nor in vitro, that report lycopene bioaccessibility in tomato 
as a function of a range of different non-thermal processing technologies in comparison to thermal processing techniques seem to exist currently.

There has been increasing interest in the use of moderate intensity pulsed electric field (MIPEF) technology due to its potential to induce non-thermal cell permeability and stress reaction at the cellular level in the plant (Soliva-Fortuny, Balasa, Knorr, \& Martin-Belloso, 2009). These cell permeability and stress reactions have been reported to be beneficial in enhancing and stimulating the polyphenolic and carotenoid content in plants (Balasa, Toepfl, \& Knorr, 2006; Toepfl, Mathys, Heinz, \& Knorr, 2006; Vallverdu-Queralt, Oms-Oliu, Odriozola-Serrano, Lamuela-Raventos, Martin-Belloso, \& Elez-Martinez, 2013b). The effect of MIPEF on lycopene bioaccessibility of whole tomato fruits and their product, such as tomato juice, is however largely unknown. The concept of using MIPEF technology as a pre-processing treatment in advance of other processing techniques to enhance lycopene bioaccessibility is also under explored, and successful implementation of such a pre-treatment could result in products with an additional advantage with regards to nutritive value.

Hence, the aims of this study were two fold. Firstly, to investigate the feasibility of MIPEF as a pre-treatment for the whole tomato fruit in order to enhance the lycopene in vitro bioaccessibility. Secondly, to further enhance lycopene bioaccessibility of tomato juice products by evaluating the best combination of conventional and novel processing technologies.

\section{MATERIALS AND METHODS}

\subsection{Materials}

Tomato fruits of Pitenza (origin- Spain) variety at fully ripe stage were purchased in several batches from wholesalers in Northern Ireland (UK) between December 2014 and October 2015. In total, $60 \mathrm{~kg}$ of tomatoes were purchased in six batches and graded before processing (mean 
weight, $85 \pm 5 \mathrm{~g}$ and mean circumference, $15 \pm 1 \mathrm{~cm}$ ); odd shaped and sized tomatoes were excluded. The all-trans and 5-cis lycopene standards were purchased from CaroteNature (Lupsingen, Switzerland) and all other chemicals were purchased from Sigma-Aldrich (Dorset, UK). All chemicals were of analytical grade. Packaging materials (polyethylene/polyamide film, $200 \mu \mathrm{m}$ thickness) were obtained from Scobie \& Junor (Mallusk, UK).

\subsection{Pre-treatment: optimisation of MIPEF in the whole tomato fruit}

Moderate intensity pulsed electric field (MIPEF) treatments were conducted in batch mode using a laboratory-scale PEF unit (ELCRACK HVP 5, DIL, German Institute of Food Technologies, Quackenbruck, Germany) located within the School of Agriculture and Food Science, University College Dublin. A stainless steel parallel treatment chamber with $8 \mathrm{~cm}$ gap was used, and tomato fruit was placed in the treatment chamber and filled with tap water. Whole ripe tomatoes were subjected to $0,1,20$ or 80 mono-polar pulses (pulse width- $4 \mu$ s, frequency- $0.1 \mathrm{~Hz}$, electrical field strength (EFS)- $1 \mathrm{kV} / \mathrm{cm}$ ), which is equivalent to $0,4,80$ and $320 \mu$ s treatment duration, respectively. MIPEF-treated and untreated fruits were collected and to investigate the potential to induce stress reactions in plant systems in production of secondary metabolites, fruits were immediately refrigerated at $4{ }^{\circ} \mathrm{C}$ and held for $48 \mathrm{~h}$. Each treatment consisted of three replicates with six fruits per replicate, and the whole experiment was conducted on two separate days as independent batches. Samples were withdrawn after 0, 24 and $48 \mathrm{~h}$ holding period (dark storage) and subjected to analysis. Samples used to measure lycopene in vitro bioaccessibility were stored at $-80{ }^{\circ} \mathrm{C}$, while the rest of the samples were refrigerated $\left(4^{\circ} \mathrm{C}\right)$ for microstructure analysis.

\subsection{Processing of tomato juice}




\subsubsection{Preparation of tomato juice for processing}

Tomatoes were subjected to MIPEF treatment ( 1 pulse, $4 \mu$ s pulse width, $1 \mathrm{kV} / \mathrm{cm}$ EFS, $0.1 \mathrm{~Hz}$ ) and refrigerated immediately after the treatment at $4{ }^{\circ} \mathrm{C}$ for $24 \mathrm{~h}$. Untreated tomatoes as a control treatment were also refrigerated at $4{ }^{\circ} \mathrm{C}$. After $24 \mathrm{~h}$ holding at $4{ }^{\circ} \mathrm{C}$, untreated and MIPEFtreated tomatoes were separately blended (120 s at $10000 \mathrm{rpm})$ using a domestic blender and filtered through $2 \mathrm{~mm}$ steel sieve and subjected to processing as described below.

\subsubsection{Thermal and non-thermal processing of tomato juice}

In order to investigate the contribution of each processing step to increasing the lycopene in vitro bioaccessibility, starting from fresh tomato to processed juice, the experiment was conducted with six treatments (fresh, MIPEF, MIPEF+blanching (B), MIPEF+B+US, MIPEF+B+HIPEF and MIPEF+B+US+HIPEF) and each treatment consisted of three replicates. The overall experimental design, representing both pre-treatment and processing experiments, is depicted in Figure 1. Blanching $\left(90{ }^{\circ} \mathrm{C} / 2 \mathrm{~min}\right.$ ) step was conducted using a water bath (Grant OLS 200, Wiltshire, UK) after filling the juice $(50 \mathrm{ml})$ into heat sealed pouches $(10 \times 10 \mathrm{~cm})$. The juice temperature was monitored using K-type thermocouples fitted to a data logger (Grant squirrel 2040 series, Wiltshire, UK). Blanched samples were cooled immediately using an ice bath and then subjected to US and HIPEF processing. US processing was conducted using a $400 \mathrm{~W}$ ultrasonic processor (Model No. UIP 1000 hd, Hielscher, Germany) with a $19 \mathrm{~mm}$ diameter probe. Samples $(50 \mathrm{ml})$ were processed at a constant frequency of $20 \mathrm{kHz}$ and $20 \%$ amplitude level for $7 \mathrm{~min}$ according to Adekunte et al. (2010). Tomato juice samples were placed in a $50 \mathrm{ml}$ beaker and juice temperature during sonication increased to $65-70{ }^{\circ} \mathrm{C}$. The ultrasonic probe was submerged to a depth of $25 \mathrm{~mm}$ in the sample. 
HIPEF treatments were also conducted in batch mode using a laboratory scale PEF unit (ELCRACK HVP 5, DIL, German Institute of Food Technologies, Quackenbruck, Germany) located within the School of Agriculture and Food Science, University College Dublin. A stainless steel parallel treatment chamber with $8 \mathrm{~cm}$ gap was used to process $50 \mathrm{ml}$ of juice. Treatment was set up at $35 \mathrm{kV} / \mathrm{cm}$ for $1500 \mu$ s using $4 \mu$ s width pulses and a frequency of 100 Hz (Odriozola-Serrano et al., 2009). As a control, heat sealed pouches of the same tomato juice were subjected to thermal processing $\left(95^{\circ} \mathrm{C} / 20 \mathrm{~min}\right)$ using a water bath. The cis and trans lycopene contents, lycopene in vitro bioaccessibility, and colour of the all processed samples were evaluated as per methods described below.

\subsection{Physical and chemical analysis of whole tomato and tomato juice}

\subsubsection{Microstructure}

Scanning electron microscopy (SEM) was employed to evaluate the impact of processing on the microstructure of tomato. Small pieces of mesocarp of treated and untreated tomatoes were taken from the outer mesocarp close to the skin. All pieces were cut with a scalpel to sizes of approximately $0.5 \times 2.0 \times 2.0 \mathrm{~mm}$, immediately placed in $5 \%$ glutaraldehyde (in $0.1 \mathrm{M}$ sodium phosphate buffer, $\mathrm{pH} 7.4$ ) for $24 \mathrm{~h}$ at $4{ }^{\circ} \mathrm{C}$, and then dipped three times (20 min each) in $0.1 \mathrm{M}$ sodium phosphate buffer, three times (20 min each) in double-distilled water, and dehydrated in a series of ethanol (50-100\%) solutions. Additionally, samples were dipped in hexamethyldisilazane (HMDS) solution for $20 \mathrm{~min}$ and then dried under a fume hood overnight.

Before taking the microstructure images, dried tissue samples were fixed on steel supports and coated with gold using an Emitech metaliser (Quorum Technologies, K575 X, Kent, UK) at 
1100-1200 V, $5 \mathrm{~mA}$ for $10 \mathrm{~min}$. Samples were observed using a scanning electron microscope (FEI, Qunta3D FEG, Oregon, USA) at $20 \mathrm{kV}$.

\subsubsection{Determination of lycopene in vitro bioaccessibility}

Tomato samples (2.5 g) were subjected to a simulated human gastric and small intestinal digestion based on the method described by Hedren, Mulokozi \& Svanberg (2002) with a few modifications (Anese et al., 2013; Stratakos, Delgado-Pando, Linton, Patterson \& Koidis, 2016) to determine the in vitro bioaccessibility of lycopene. Amber tubes and vials were used at all steps to protect samples from light. The digests were centrifuged (SORVALL Legend RT, Woburn, Germany) at $5000 \mathrm{~g}$ for $1 \mathrm{~h}$ to remove the non-digested particles (Failla, Huo, \& Thakkar, 2008). The lycopene content in the supernatant was measured using the method described below (2.4.3). The lycopene bioaccessibility of a sample is reported as the ratio (\%) of the in vitro bioaccessible lycopene content to the corresponding lycopene content of the sample. The simple static in vitro gastro- intestinal track (GIT) model used in this study cannot simulate the complex conditions that occur within the human gastro-intestinal tract. However, the approach of using digestion models is still useful in terms of rapid evaluation of nutrient bioaccessibility in foods, which subsequently can be investigated in depth using animal or human trials.

\subsubsection{Determination of cis- and trans-lycopene isomers using high performance liquid chromatography (HPLC)}

Lycopene was extracted from both undigested sample and digesta (content resulting after digestion) of whole tomato and tomato juice according to the method described by Sadler, Davis \& Dezman (1990) with minor modifications. Lycopene extraction from undigested whole tomato 
and tomato juice was carried out using freeze dried samples $(0.25 \mathrm{~g})$ and centrifuged digesta (15 $\mathrm{ml})$ obtained after digestion with $25 \mathrm{ml}$ of hexane:ethanol:acetone (2:1:1). Freeze drying was achieved using a Christ-Alpha 1-4 LD plus freeze dryer (Darmstadt, Germany). The apolar phase, containing lycopene, was separated from the polar phase using a separation funnel and concentrated under vacuum using a rotary evaporator (Stuart RE 3008, Staffordshire, UK) at 30 ${ }^{\circ} \mathrm{C}$, and subsequently reconstituted in $2 \mathrm{ml}$ hexane:dicholoromethane (4:1), filtered (Fisher PTFE filters, $0.20 \mu \mathrm{m}$ pore size, $25 \mathrm{~mm}$ diameter) and transferred to a $2 \mathrm{ml}$ amber vial.

For the analysis of lycopene isomers, an HPLC system (Waters Limited, 2695 series, Hertfordshire, UK) equipped with a diode array detector (DAD) was used. The different isomers were separated on a reversed phase C30 column $(5 \mu \mathrm{m} \times 150 \mathrm{~mm}$ × $2.0 \mathrm{~mm}$, Develosil, Macclesfield, UK). The column was thermostated at $25^{\circ} \mathrm{C}$. The initial mobile phase consisted of water (A), methanol (B) and methyl-tert-butyl-ether (C). The following gradient program was used: linear change of $4 \%$ A, $81 \%$ B and $15 \%$ C for 5 min, followed by $4 \%$ A, $36 \%$ B and $60 \%$ $\mathrm{C}$ for next $5 \mathrm{~min}$ and then switched to the initial conditions of $4 \% \mathrm{~A}, 81 \% \mathrm{~B}$ and $15 \% \mathrm{C}$, over another $10 \mathrm{~min}$.

All-trans and different cis- lycopene isomers were identified based on retention time and previously reported spectral characteristics (Re, Fraser, Long, Bramley \& Rice-Evans, 2001; Yeum, Booth, Sadowski, Liu, Tang \& Ang Krinsky, 1996). For the quantification of lycopene, HPLC-DAD peak responses were measured at $472 \mathrm{~nm}$ and appropriate calibration curves were generated from peak areas of all-trans and 5-cis lycopene standards. Since no standards were available for other cis-lycopene isomers, they were quantified based on the method of Colle, Lemmes, Van Buggenhout, Van Loey \& Hendrickx (2010b) and expressed as total cis-lycopene. The lycopene isomer contents of tomato juice were calculated on a fresh weight basis, i.e. $\mu \mathrm{g} / \mathrm{g}$. 


\subsubsection{Colour measurements}

The colour of tomato juice samples was evaluated using a Konica Minolta portable colorimeter (CR-400, Konica Minolta, Japan). The instrument was calibrated using a white standard tile $(X=$ 00.31, $\mathrm{Y}=93.00, \mathrm{Z}=0.3324)$. The tomato juice samples were placed in a transparent cup and the colorimeter was placed on the juice and $\mathrm{L}, \mathrm{a}, \mathrm{b}$ values were directly taken from the colorimeter. Each measurement reported represents the average of three readings. L represents lightness, $+\mathrm{a}$ represents redness, $-\mathrm{a}$ represents greenness, $+\mathrm{b}$ yellowness and $-\mathrm{b}$ represents blueness. The Hue value $(\mathrm{a} / \mathrm{b})$ was calculated based on measured $\mathrm{a}$ and $\mathrm{b}$ values.

\subsubsection{Statistical analysis}

Significance of the results and statistical differences were analysed using the SPSS (IBM, New York) statistical package. Data were analysed by two-way analysis of variance (ANOVA) procedure. Duncan multiple range test (DNMRT) was employed to determine the differences among treatment means, with $p<0.05$ considered statistically significant.

\section{RESULTS AND DISCUSSION}

\subsection{MIPEF as a pre-treatment in whole tomatoes}

\subsubsection{Effect of MIPEF treatment parameters on lycopene content of whole tomatoes}

The contents of total lycopene, all-trans and cis-lycopene isomers of different treatments, before and after digestion (digesta), during a $48 \mathrm{~h}$ holding period are shown in Table 1 . The fresh sample showed the lowest lycopene content $(30.68 \pm 0.81 \mu \mathrm{g} / \mathrm{g} F W)$ at zero holding time without MIPEF treatment, which was in accordance with the value described in the literature (Svelander, Tiback, Ahrne, Langton, Svanberg \& Alminger, 2010). The level of trans-lycopene isomers of 
the fresh samples (84.6\%) are also in line with those described by other authors, which report trans- lycopene content in fresh tomatoes varied from 35-96\% of total lycopene with 5-, 9-, 13and 15-cis lycopene being the main cis- isomers detected (Frohlich, Conrad, Schmid, Breithaupt $\&$ Bohm, 2007). In addition to the dominant all-trans and the two cis-lycopene isomers, $\beta$ carotene could also be detected in the extracts (data not shown).

Both trans- and cis- isomers content in fresh tomatoes remained stable during $48 \mathrm{~h}$ holding period without significant differences at $\mathrm{p}<0.05$ while enhancement of these isomers were observed in 4 and $80 \mu$ s treated fruits, except the cis- content in $4 \mu$ s treatment. The highest duration treatment $(320 \mu \mathrm{s})$ showed the best lycopene enhancement immediately after the treatment (trans-lycopene $50.57 \pm 3.77 \mu \mathrm{g} / \mathrm{g}$ FW and cis-lycopene $7.41 \pm 0.69 \mu \mathrm{g} / \mathrm{g} \mathrm{FW}$ ) but decreased thereafter. The behaviour of trans- and cis- lycopene isomers in response to MIPEF duration and holding period in digesta, as calculated by the amount present in digesta, is shown in Table 1 and followed a similar pattern to the undigested samples of corresponding treatment. However, the trans- isomers content available in digesta was significantly reduced in all treatments $(0.87 \pm 0.11-2.13 \pm 0.24 \mu \mathrm{g} / \mathrm{g} F W)$ in comparison to the amount present in undigested samples $(24.84 \pm 2.08-50.57 \pm 3.77 \mu \mathrm{g} / \mathrm{g} \mathrm{FW})$. The cis- content of 4 and $80 \mu \mathrm{s}$ treated samples increased $24 \mathrm{~h}$ after the treatment and decreased thereafter, while $320 \mu$ s treated sample showed continuous decreases. Similar decreases of cis- and trans-lycopene contents were reported by Valliverdu-Queralt, Odriozola-Serrano, Oms-Oliu, Lamuela-Raventos, Elez-Martinez \& MartinBelloso (2013a) for MIPEF treated $(2 \mathrm{kV} / \mathrm{cm}, 120 \mu \mathrm{s})$ tomato $24 \mathrm{~h}$ after the treatment.

According to the literature, application of PEF to biological cell material makes the cell membrane permeable, which has proven effective in improving the polyphenol and pigments extractability without affecting other quality attributes of fruits and vegetables (Balasa et al., 
2006; Vallverdu-Queralt et al., 2013b). The external electrical field, in the form of short repeated pulses ( $\mu$ s or ms) of a high voltage $(\mathrm{kV})$, induces either temporary (reversible) or permanent (irreversible) pores in the cell membrane. The reversible cell permeability is reported to be useful in inducing stress reactions in plant systems and stimulates the generation of secondary cell metabolites (Galindo, Dejmek, Lundgren, Rasmusson, Vicente \& Moritz, 2009; Guderjan, Toepfl, Angersbach \& Knorr, 2005; Toepfl et al., 2006) and consequently synthesis of carotenoids in plants as a defence response to stress (Balasa et al., 2006; Vallverdú-Queralt, Medina-Remon, Casals-Ribes, Andres-Lacueva, Waterhouse \& Lamuela-Raventos, 2012). Therefore, enhancement of lycopene content immediately after the treatment and further increase $24 \mathrm{~h}$ after the treatment could be explained due to the cell membrane permeability and lycopene synthesis as a response to PEF treatment. Subsequent reduction after a $48 \mathrm{~h}$ holding period might be due to the reversible nature of the tissue permeability after some time period (Soliva-Fortuny et al., 2009).

\subsubsection{Effect of MIPEF treatment parameters on microstructure of whole tomatoes}

The results obtained from the quantification of cis- and trans- lycopene contents were supported by the microstructural changes observed in microscopic images taken from the SEM. Fresh or untreated tomato at $0 \mathrm{~h}$, showed isodiametric parenchyma cells (Figure 2A), and this cellular structure of fresh samples remained stable throughout the holding period. With increasing treatment duration (80 and $320 \mu$ s), fruits show progressively more irregular cell wall structure, such as folds in cell walls and loss of smoothness (Supplementary material), unlike in fresh samples. Tomato fruits subjected to $80 \mu \mathrm{s}$, clearly showed the folds in the cell wall $24 \mathrm{~h}$ posttreatment (Supplementary material) and no folds can be seen at $48 \mathrm{~h}$ post-treatment 
(Supplementary material). This might suggest the reversible nature of the cell wall structure as a result of MIPEF treatment, according to similar observations in the literature (Angersbach, Heinz \& Knorr, 2000). The longest treatment $(320 \mu \mathrm{s})$ showed the most dramatic changes, with more irregular and larger folds in the cell wall (Supplementary material) observed both immediately and $24 \mathrm{~h}$ after the treatment. The appearance of the cell wall $48 \mathrm{~h}$ post-treatment resembled a dried material (Supplementary material), which can be attributed to detrimental damage caused by high duration treatment. Hence, the microstructural differences observed during the holding period duration might be due to the previously reported pore formation phenomenon as a consequence of the MIPEF treatment (Angersbach et al., 2000) and this reversible cell permeability and irreversible breakdown of cell wall structure is expected to directly affect the micronutrient accessibility, not only of the tomato fruit but in general of all food producing plants (Soliva-Fortuny et al., 2009).

\subsubsection{Effect of MIPEF treatment parameters on cis- and trans- lycopene bioaccessibility}

Investigations of the in vitro bioaccessibility of lycopene from tomato are very limited, but values reported for the amount present in digesta are fairly low and in the range of $2-13 \%$ of total content (Gartner, Stahl \& Sies, 1997; Stahl \& Sies, 1992; Svelander et al., 2010). Changes of trans- and cis- lycopene bioaccessibility as a response to MIPEF treatment duration and holding period are shown in Figure 3. Human studies have demonstrated the nutritional benefits of cis- isomers in tomato products, because these compounds seem to be better absorbed in the intestine than the trans- isomers (Takeoka, Dao, Flessa, Gillespie, Jewell \& Huebner, 2001). Theresults in this study also support the findings of Takeoka et al. (2001), as cis-lycopene showed higher bioaccessibility (19-31\%) in comparison to trans-lycopene bioaccessibility (2.38- 
$6.18 \%)$. The highest trans- $(6.2 \%)$ and cis- $(31 \%)$ lycopene bioaccessibilities were shown by the $4 \mu \mathrm{s}$ treated samples immediately and $24 \mathrm{~h}$ after the treatment, respectively. Hence, the process of trans- to cis- isomerisation seems beneficial in terms of potential health impact of tomato juice, since the cis- isomers are more bioaccessible (approximately 5 times) in comparison to trans- isomers.

According to the results obtained from the MIPEF pre-treatment investigation, a treatment duration of $4 \mu \mathrm{s}$ (one pulse at $0.1 \mathrm{~Hz}, 1 \mathrm{kv} / \mathrm{cm}$ ) and a $24 \mathrm{~h}$ holding period were the most effective in enhancing total lycopene bioaccessibility among all treatments. This treatment $(4 \mu \mathrm{s})$ showed $7.8 \%$ total lycopene bioaccessibility immediately after the treatment increasing up to $9.6 \%$ after $24 \mathrm{~h}$ holding period, and decreasing thereafter, reaching $8.1 \%$ after $48 \mathrm{~h}$ (Table 1).

\subsection{Processing of tomato juice}

\subsubsection{Effect of thermal and non-thermal processing on lycopene content}

The change in lycopene content of undigested samples and digesta during each processing step is shown in Table 2. Untreated juice contained $29.58 \pm 2.03 \mu \mathrm{g} / \mathrm{g}$ FW total lycopene content that consisted of $88 \%$ all-trans lycopene, which is in accordance with the results of Hart and Scott (1995) who reported that all-trans lycopene accounts for 56-91\% of the total lycopene depending on the red tomato variety. Fresh tomato juice had $25.90 \pm 1.78 \mu \mathrm{g} / \mathrm{g} \mathrm{FW}(87.6 \%)$ of all-trans and $3.68 \pm 0.03 \mu \mathrm{g} / \mathrm{g}$ FW (12.4\%) cis- isomers content, while Colle et al. (2010b) claimed approximately three times higher trans- and cis- isomers contents in fresh tomato puree in comparison to our findings. Regarding the different treatment effects, all-trans lycopene retention was high in all cases; with dramatic changes in cis-lycopene content being observed for several different treatments. Enhancement of cis-lycopene content by 32.6, 4.89 and $151.9 \%$ 
was achieved by a single moderate intensity pulsed electric field treatment (MIPEF), MIPEF accompanied by blanching (MIPEF+B), and by a combination of moderate and high PEF treatment with intermediate blanching $(\mathrm{MIPEF}+\mathrm{B}+\mathrm{HIPEF})$, respectively, while reductions of 55.7, 22.5 and 23.3\% were observed in MIPEF+B+US, MIPEF+B+US+HIPEF and TP samples, respectively. It has been reported that heat induced by blanching or HIPEF processing of juices may increase carotenoid level, including lycopene (Odriozola-Serrano et al., 2009; VallverduQueralt et al., 2013b), due to activation of carotenoid isomerase enzymes and release of the carotenoids after removing the cellular barrier (Lemmens, Colle, Van Buggenhout, Palmero, Van Loey \& Hendrickx, 2014; Van Buggenhout, Alminger, Lemmens, Colle, Knockaert \& Moelants, 2010). Conflicting results regarding lycopene bioaccessibility and isomerisation during thermal processing have been reported, reflecting the complexity of cell behaviour during processing. Seybold, Frohlich, Otto \& Bohm (2004) reported no lycopene isomerisation in typical tomato processing, while others (Boileau, Boileau \& Erdman, 2002; Vallverdu-Queralt et al., 2013b) indicated the formation of cis-lycopene during thermal treatment of tomato puree and juice. The loss of cis- and trans- isomers due to degradation and oxidation during heat treatment have also been explored (Colle et al., 2010b; Svelander et al., 2010). Here, the different behaviour of trans- and cis- isomer lycopene content of tomato juice digesta is presented in comparison to the undigested counterpart (Table 2). Fresh tomato exhibited 1.30 $\pm 0.02 \mu \mathrm{g} / \mathrm{g}$ FW of trans- and $1.08 \pm 0.16 \mu \mathrm{g} / \mathrm{g}$ FW of cis-lycopene content. All-trans lycopene content of MIPEF+B and TP samples, decreased by $64 \%$ while cis- lycopene content increased by 55 and $12 \%$, respectively, in comparison to fresh samples. All-trans lycopene content after all other treatments increased significantly, with the highest content shown after the MIPEF+B+HIPEF treatment $(4.01 \pm 0.02$ $\mu \mathrm{g} / \mathrm{g} \mathrm{FW})$. On the other hand, cis- isomer present in the digesta increased after all treatments, 
with the highest content shown by the treatment of MIPEF+B+HIPEF $(5.04 \pm 0.26 \mu \mathrm{g} / \mathrm{g} \mathrm{FW})$, with the exception of the MIPEF+B+US treatment. Boileau et al. (2002) also observed that more than $50 \%$ of carotenoids found in the human body are in the cis- isomeric form.

\subsubsection{Effect of thermal and non-thermal processing on lycopene in vitro bioaccessibility}

In addition to the lycopene isomer content, the in vitro bioaccessible lycopene content of the fresh and processed tomato juice was determined. This is reported as the ratio (\%) of the lycopene isomer content in digesta to the lycopene isomer content in corresponding undigested treatment (Figure 4), which represents the percentage of the containing lycopene that is released from the tomato matrix during digestion. In the untreated tomato juice $5.02 \pm 0.09 \%$ trans- and $46.95 \pm 4.35 \%$ cis- lycopene isomers were bioaccessible, which is in contrast to Colle et al. (2010b) who reported $15 \%$ bioaccessibility in each isomer for untreated tomato pulp. Upon treatment, $\mathrm{PEF}+\mathrm{B}+\mathrm{HIPEF}$ and $\mathrm{PEF}+\mathrm{B}+\mathrm{US}+\mathrm{HIPEF}$ were effective to enhance the trans-lycopene bioaccessibility significantly, while B, TP and B+US treatments showed lower trans-lycopene bioaccessibilities of $1.22,1.49$ and $3.85 \%$, respectively, in comparison to fresh tomatoes. The bioaccessibility of cis-lycopene isomers in all treatments were comparatively high and within the range of $43 \%(\mathrm{TP})$ to $68 \%(\mathrm{MIPEF}+\mathrm{B}+\mathrm{US}+\mathrm{HIPEF})$, agreeing with figures reported in the literature.

It has previously been reported that cis-lycopene isomers are less likely to crystallise or aggregate, and, therefore, they are thought to be more soluble in micelles (Boileau, Merchen, Wasson, Atkinson, \& Erdman, 1999). In addition, studies in human and animal models support the hypothesis that cis- isomers are more efficiently digested (Boileau et al., 1999; Porrini, Riso, \& Testolin, 1998; Stahl \& Sies, 1992). However, the high bioaccessible nature of cis- isomers does not have significant impact when considering the total effect, since trans-lycopene 
dominates in the processed samples (more than 84\%) similar to fresh juice. Colle et al. (2010b) reported $25 \%$ trans- and $35 \%$ cis- biaccessibility after intense heat treatment $\left(140{ }^{\circ} \mathrm{C} / 30 \mathrm{~min}\right)$ of tomato pulp. Previous in vivo studies have shown that the absorption of lycopene from industrially processed (mechanically and thermally) tomatoes is higher than from fresh tomatoes (Gartner et al., 1997; Porrini et al., 1998). Considering total lycopene (both cis- and trans-) bioaccessibility, our results for TP samples (4.95\%) are in very close agreement with the values reported by Svelander et al. (2010) and Ryan, O'Connell, O’Sullivan, Aherne \& O'Brien (2008). An improvement in lycopene bioaccessibility after HTST blanching $\left(90^{\circ} \mathrm{C} / 10 \mathrm{~min}\right)$ followed by boiling (100 $\left.{ }^{\circ} \mathrm{C} / 20 \mathrm{~min}\right)$ was reported by Svelander et al. (2010); however, the maximum bioaccessibility that they obtained was $29.3 \%$, indicating that a large quantity of the lycopene was still bound to the food matrix.

In nature, lycopenes are tightly bound to subcellular lipids and binding proteins, which determine their release during digestion. During thermal processing proteins might form aggregates that are not available during digestion, hindering their subsequent incorporation into micelles, which is where lycopene might become embedded (Palmero, Lemments, Hendrickx \& Loey, 2014). Takada and Nelson (1983) pointed out that upon heating, proteins in tomato denature, resulting in an irreversible complex formation. On the other hand, specific processing techniques can also induce new or additional barriers for carotenoid bioaccessibility; examples have been shown in the studies of Colle, Van Buggenhout, Van Loey \& Hendrickx (2010a), Panozzo, Lemmens, Van Loey, Manzocco, Nicoli \& Hendrickx (2013) and Svelander, Lopez-Sanchez, Pudney, Schumm \& Alminger (2011) (high pressure homogenisation), and in the studies of Anese, Bot, Panozzo, Mirolo \& Lippe (2015) and Anese et al. (2013) (ultrasound treatments). All these studies concluded that high pressure homogenisation or ultrasound treatments probably resulted in the 
formation of a strong fibre network which hinders the release of lycopene from the tomato matrix in comparison to untreated tomato pulp. Interestingly, in the present study, cis- isomers bioaccessibility of US processed tomato juice was enhanced. This may be attributable to the MIPEF and blanching treatment applied prior to processing. Therefore, there is a strong case that pre- or post- treatment is needed for ultrasound processing in order to release the trapped lycopene during processing.

\subsubsection{Effect of thermal and non-thermal processing on colour of tomato juice}

Colour in the tomato is due to the presence of carotenoids, mainly lycopene; hence measuring colour is an indirect indicator of lycopene quantity present in a product. Colour properties as assessed by lightness (L value) and redness (a/b) of processed and unprocessed tomato juice were determined to investigate impact of processing method on sensory qualities directly after the treatment. By comparing the samples, marked colour differences were noticed (data not shown). Tomato juice obtained from fresh and MIPEF treated fruits showed the lowest redness indicated by the highest $\mathrm{L}$ values of $14.12 \pm 2.53$ and $12.95 \pm 2.94$, respectively. Colour was improved further by blanching and processing, showing lower L values in all processed samples ranging from 6.1-7.1. The colour of tomato juice is a direct reflection of lycopene content, but not necessarily related to the lycopene bioaccessibility. For instance, thermally processed samples showed lower bioaccessibility in comparison to other treated samples though it had higher redness (lower L value, 6.32 \pm 0.18 ).

\section{CONCLUSIONS}


The results of this study clearly demonstrate the benefit of MIPEF as a pre-processing treatment to enhance the lycopene bioaccessibility of whole tomato and further enhancement of lycopene bioaccessibility by subsequent processing. Total carotenoid and cis- and trans-lycopene contents could be enhanced by increasing the pre-treatment duration (from 4-320 $\mu \mathrm{s}, \mathrm{EFS}-1 \mathrm{kV} / \mathrm{cm}$ ) to increase cell permeability. The lowest duration $(4 \mu \mathrm{s})$ treatment showed the highest total lycopene bioaccessibility (9.6\%) after a $24 \mathrm{~h}$ holding period. During subsequent tomato juice processing, total lycopene content increased after all treatments with the highest content $(96.1 \%)$ shown by MIPEF+B+HIPEF treatment in comparison to fresh tomato juice. Results revealed that cis-lycopene was approximately five times more bioaccessible than trans-lycopene, and the highest cis- $(68.67 \%)$ and trans- $(8.23 \%)$ lycopene bioaccessibilities were obtained by the $\mathrm{MIPEF}+\mathrm{B}+\mathrm{HIPEF}$ and MIPEF+B+US+HIPEF treatments, respectively. However, the former treatment (MIPEF+B+US+HIPEF) was more effective in terms of total lycopene bioaccessibility $(15.6 \%)$ in comparison to the thermally treated samples $(4.95 \%)$. Hence, these findings allow for a better understanding of lycopene bioaccessibility increases in tomato juice using both thermal and non-thermal technologies; an area that has not been explored to date. Furthermore, the study quantified the negative and positive effects of each of the different processing steps on the cisand trans- lycopene contents as well as their in vitro bioaccessibilities. These findings will be of value to the tomato juice processing industry where measures need to be taken in order to enhance the nutritional and functional quality attributes, apart from sensory and safety parameters.

\section{Acknowledgements}


This research was undertaken when Lasanthi Jayathunge was in receipt of a $\mathrm{PhD}$ studentship from the Commonwealth Scholarship Commission, UK.

\section{Conflict of interest statement}

The authors declare no conflict of interest.

\section{REFERENCES}

1. Adekunte, A., Tiwari, B.K., Scannell, A., \& O’Donnell, C. (2010). Effect of sonication on colour, ascorbic acid and yeast inactivation in tomato juice. Food Chemistry, 122, $500-507$.

2. Anese, M., Bot, F., Panozzo, A., Mirolo, G., \& Lippe, G. (2015). Effect of ultrasound treatment, oil addition and storage time on lycopene stability and in vitro bioaccessibility of tomato pulp. Food Chemistry, 172, 685-691.

3. Anese, M., Mirolo, G., Beraldo, P., \& Lippe, G. (2013). Effect of ultrasound treatments of tomato pulp on microstructure and lycopene in vitro bioaccessibility. Food Chemistry, 136, 458-463.

4. Angersbach, A., Heinz, V., \& Knorr, D. (2000). Effects of pulsed electric fields on cell membranes in real food systems. Innovative Food Science and Emerging Technologies, 1, 135-149.

5. Balasa, A., Toepfl, S., \& Knorr, D. (2006). Pulsed electric field treatment of grapes. Food Factory of the Future 3, Gothenburg, Sweden. 
6. Boileau, A.C., Merchen, N.R., Wasson, K., Atkinson, C.A., \& Erdman, J.W. (1999). Cis-lycopene is more bioavailable than trans-lycopene in vitro and in vivo in lymphcannulated ferrets. Journal of Nutrition, 129, 1176-1181.

7. Boileau, T.W., Boileau A.C., \& Erdman, J.W. (2002). Bioavailability of all-trans and cis isomers of lycopene. Experimental Biology and Medicine, 227, 914-919.

8. Colle, I., Lemmes, L., Van Buggenhout, S., Van Loey, A., \& Hendrickx, M.E. (2010b). Effect of thermal processing on the degradation, isomerisation and bioaccessibility of lycopene in tomato pulp. Journal of Food Science, 75, C753-C759.

9. Colle, I., Van Buggenhout, S., Van Loey, A., \& Hendrickx, M.E. (2010a). High pressure homogenation followed by thermal processing of tomato pulp: influence on microstructure and lycopene in vitro bioaccessibility. Food Research International, 43, 2193-2200.

10. Failla, M.L., Huo, T., \& Thakkar, S.K. (2008). In vitro screening of relative bioaccessibility of carotenoids from foods. Asia Pacific Journal of Clinical Nutrition, 17(S1), 200-203.

11. Frohlich, K., Conrad, J., Schmid, A., Breithaupt, D.E., \& Bohm, V. (2007). Isolation and structural elucidation of different geometrical isomers of lycopene. International Journal for Vitamin and Nutrition Research, 77, 369-375.

12. Galindo, F.G., Dejmek, P., Lundgren, K., Rasmusson, A.G., Vicente, A., \& Moritz, T. (2009). Metabolomic evaluation of pulsed electric field induced stress on potato tissue. Planta, 230, 469-479. 
13. Gartner, C., Stahl, W., \& Sies, H. (1997). Lycopene is more bioavailable from tomato paste than from fresh tomatoes. American Journal of Clinical Nutrition, 66, 116-122.

14. Guderjan, M., Toepfl, S., Angersbach, A., \& Knorr, D. (2005). Impact of pulsed electric field treatment on the recovery and quality of plant oils. Journal of Food Engineering, 67, 281-287.

15. Hart D.J., \& Scott, K. (1995). Development and evaluation of an HPLC method for the analysis of carotenoids in foods, and the measurement of the carotenoid content of vegetables and fruits commonly found in the UK. Food Chemistry, 54, 101-111.

16. Hedren, E., Mulokozi, G., \& Svanberg, U. (2002). In vitro bioaccessibility of carotenes from green leafy vegetables cooked with sunflower oil or red palm oil. International Journal of Food Science and Nutrition, 53, 445-453.

17. Krebbers, B., Matser, A.M., Hoogerwerf, S.W., Morzelaar, R., Momassen, M.M., \& Van den berg, R.W. (2003). Combined high pressure and thermal treatments for processing of tomato puree; evaluation of microbial inactivation and quality parameters. Innovative Food Science and Emerging Technologies, 4, 377-385.

18. Lemmens, L., Colle, I., Van Buggenhout, S., Palmero, P., Van Loey, A., \& Hendrick M. (2014). Carotenoid bioaccessibility in fruit- and vegetable based food products as affected by product (micro) structural characteristics and the presence of lipids: A review. Trends in Food Science and Technology, 38, 125-135.

19. Mosqueda-Melgar, J., Raybaudi-Massilia, R. M., \& Martín-Belloso, O. (2012). Microbiological shelf life and sensory evaluation of fruit juices treated by high 
intensity electric fields and antimicrobials. Food and Bioproducts Processing, 90, 205-214.

20. Nguyen, P., \& Mittal, G.S. (2007). Inactivation of naturally occurring microorganisms in tomato juice using pulsed electric field (PEF) with and without antimicrobials. Chemical Engineering and Processing, 46, 360-365.

21. Odriozola-Serrano, I., Aguilo-Aguayo, I., Soliva-Fortuny, R., Gimeno-Ario, V., \& Martín-Belloso, O. (2007). Lycopene, vitamin C, and antioxidant capacity of tomato juice as affected by high-intensity pulsed electric fields critical parameters. Journal of Agricultural and Food Chemistry, 55, 9036-9042.

22. Odriozola-Serrano, I., Solivia-Fortuny, R., Hernandez-Jover, T., \& Martin-Belloso, O. (2009). Carotenoid and phenolic profile of tomato juices processed by high-intensity pulsed electric fields compared with conventional thermal treatments. Food Chemistry, $112,258-266$.

23. Palmero, P., Lemments, L., Hendrickx, M., \& Loey, A.V. (2014). Role of carotenoid type on the effect of thermal processing on bioaccessibility. Food Chemistry, 157, $275-282$.

24. Panozzo, P., Lemmens, L., Van Loey, A., Manzocco, L., Nicoli, M.C., \& Hendrickx, M. (2013). Microstructure and bioaccessibility of different carotenoid species as affected by high pressure homogenisation: A case study on differently coloured tomatoes. Food Chemistry, 141, 4094-4100. 
25. Porrini, M., Riso, P., \& Testolin, G. (1998). Absorption of lycopenes from single or daily portions of raw and processed tomatoes. British Journal of Nutrition, 80, 353361.

26. Re, R., Fraser, P.D., Long, M., Bramley, P.M., \& Rice-Evans, C. (2001). Isomerization of lycopene in the gastric milieu. Biochemical and Biophysical Research Communications, 281, 576-581.

27. Ryan, L., O’Connell, O., O’Sullivan, L., Aherne, S.A., \& O’Brien, N.M. (2008). Micellarisation of carotenoids from raw and cooked vegetables. Plant Foods Human Nutrition, 63, 127-133.

28. Sadler, G., Davis, J., \& Dezman, D. (1990). Rapid extraction of lycopene and $\beta$ carotene from reconstituted tomato paste and pink grapefruit homogenate. Journal of Food Science, 55, 1460-1461.

29. Seybold, C., Frohlich, K., Otto, K., \& Bohm, V. (2004). Changes in contents of carotenoids and vitamin E during tomato processing. Journal of Agricultural and Food Chemistry, 52, 7005-7010.

30. Soliva-Fortuny, R., Balasa, A., Knorr, D., \& Martin-Belloso, O. (2009). Effects of pulsed electric fields on bioactive compounds in foods: a review. Trends in Food Science and Technology, 20, 544-556.

31. Stahl, W., \& Sies, H. (1992). Uptake of lycopene and its geometrical isomers is greater from heat-processed than from unprocessed tomato juice in humans. Journal of Nutrition, 122, 2162-2166. 
32. Stratakos, A.C., Delgado-Pando, D., Linton, M., Patterson, M.F., \& Koidis, A. (2016). Industrial scale microwave processing of tomato juice using a novel continuous microwave system. Food Chemistry, 190, 622-628.

33. Svelander, C.A., Lopez-Sanchez, P., Pudney, P.D., Schumm, S., \& Alminger, M.A. (2011). High pressure homogenization increases the in vitro bioaccessibility of $\alpha$-and $\beta$-carotene in carrot emulsions but not of lycopene in tomato emulsions. Journal of Food Science, 76, H215-H225.

34. Svelander, C.A., Tiback, E.A., Ahrne, L.M., Langton, M.I., Svanberg, U.S., \& Alminger, M.A. (2010). Processing of tomatoes: impact on in vitro bioaccessibility of lycopene and textural properties. Journal of the Science of Food and Agriculture, 90, $1665-1672$.

35. Takada, N., \& Nelson, P.E. (1983). Pectin-protein interaction in tomato products. Journal of Food Science, 448, 1408-1411.

36. Takeoka, G.R., Dao, L., Flessa, S., Gillespie, D.M., Jewell, W. T., \& Huebner, B. (2001). Processing effect on lycopene content and antioxidant activity of tomatoes. Journal of Agriculture and Food Chemistry, 49, 3713-3717.

37. Toepfl, S., Mathys, A., Heinz, V., \& Knorr, D. (2006). Potential of high hydrostatic pressure and pulsed electric fields for energy efficient and environmentally friendly food processing. Food Reviews International, 22, 405-423.

38. Valliverdu-Queralt, A., Odriozola-Serrano, I., Oms-Oliu, G., Lamuela-Raventos, R.M., Elez-Martinez, P., \& Martin-Belloso, O. (2013a). Impact of high-intensity 
pulsed electric fields on carotenoids profile of tomato juice made of moderate-intensity pulsed electric field-treated tomatoes. Food Chemistry, 141, 3131-3138.

39. Vallverdú-Queralt, A., Medina-Remon, A., Casals-Ribes, I., Andres-Lacueva, C., Waterhouse, A.L., \& Lamuela-Raventos R.M. (2012). Effect of tomato industrial processing on phenolic profile and hydrophilic antioxidant capacity. LWT-Food Science and Technology, 47, 154-160.

40. Vallverdu-Queralt, A., Oms-Oliu, G., Odriozola-Serrano, I., Lamuela-Raventos, R.M., Martin-Belloso, O., \& Elez-Martinez, P. (2013b). Metabolite profiling of phenolic and carotenoid contents in tomatoes after moderate intensity pulsed electric field treatments. Food Chemistry, 136, 199-205.

41. Van Buggenhout, S., Alminger, M., Lemmens, L., Colle, I., Knockaert, G., Moelants, K., et al. (2010). In vitro approaches to estimate the effect of food processing on carotenoid bioavailability need thorough understanding of process induced microstructural changes. Trends in Food Science \& Technology, 21(12), 607-618.

42. Yeum, K., Booth, S. L., Sadowski, J. A., Liu, C., Tang, G., \& Ang Krinsky, N. I. (1996). Human plasma carotenoid responses to the ingestion of controlled diets high in fruits and vegetables. American Journal of Clinical Nutrition, 64, 594-602. 


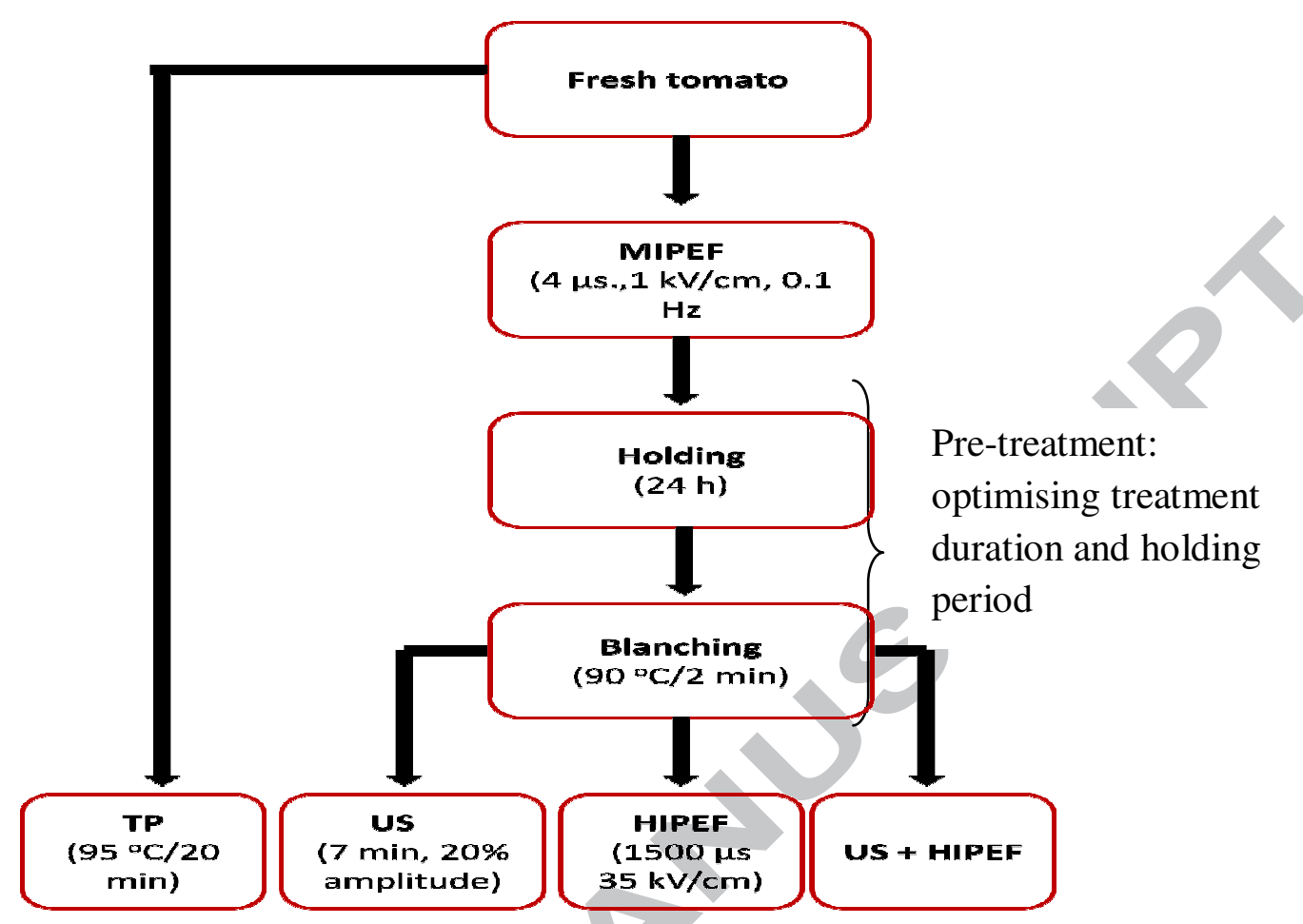

Figure 1. Overview of the experimental design for pre-treatment and full processing trials. MIPEF- Moderate Intensity Pulsed Electric Field, TP-Thermal Processing, US-Ultra Sonic and HIPEFHigh Intensity Pulsed Electric Field. 

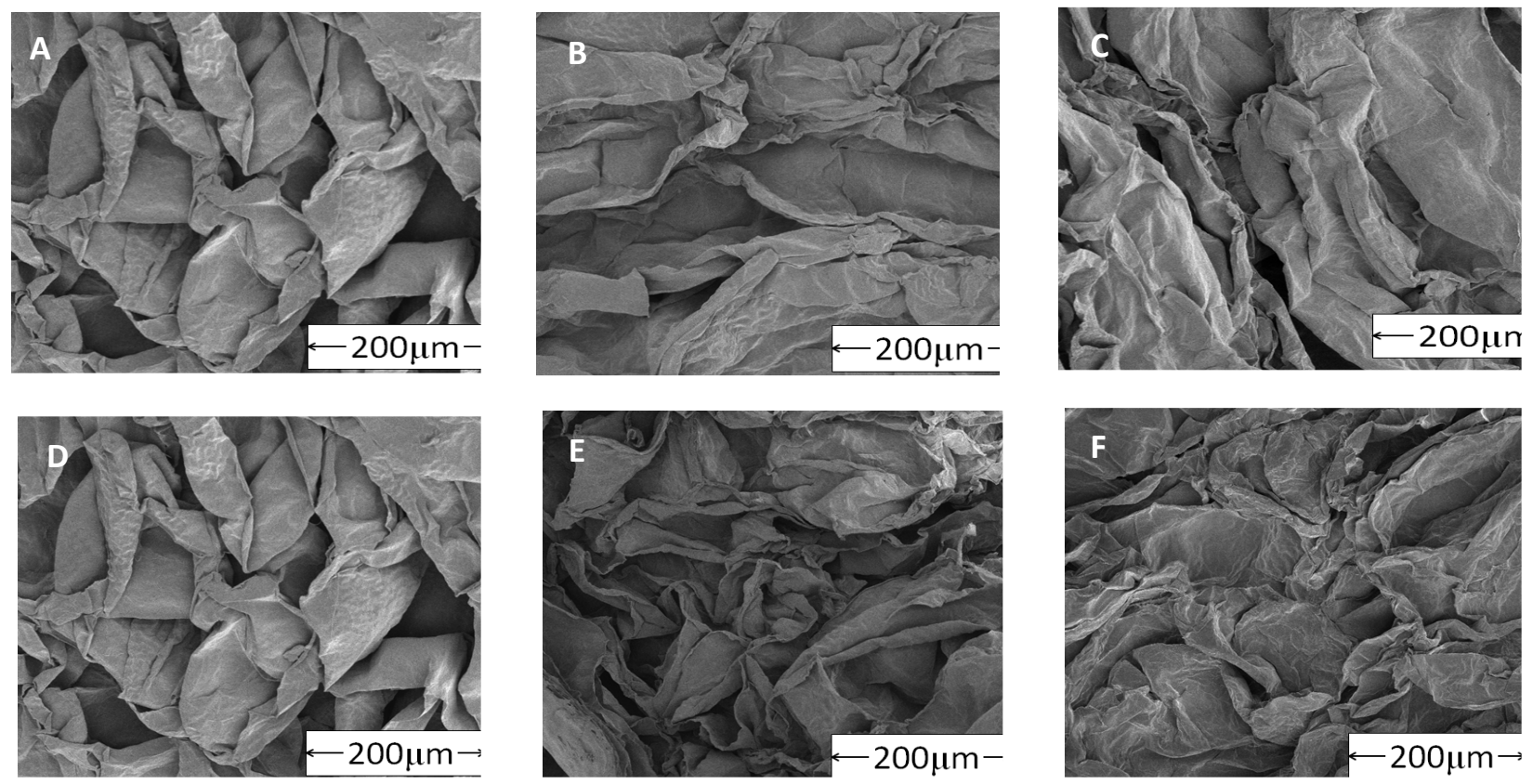

Figure 2. Effect of MIPEF treatment duration and holding period on microstructure of tomato mesocarp as shown by SEM studies . Fresh- $0 \mathrm{~h}(\mathrm{~A}), 24 \mathrm{~h}(\mathrm{~B}), 48 \mathrm{~h}(\mathrm{C})$ and $4 \mu \mathrm{s}-0 \mathrm{~h}$ (D) $24 \mathrm{~h}$ (E), $48 \mathrm{~h}(\mathrm{~F})$. 

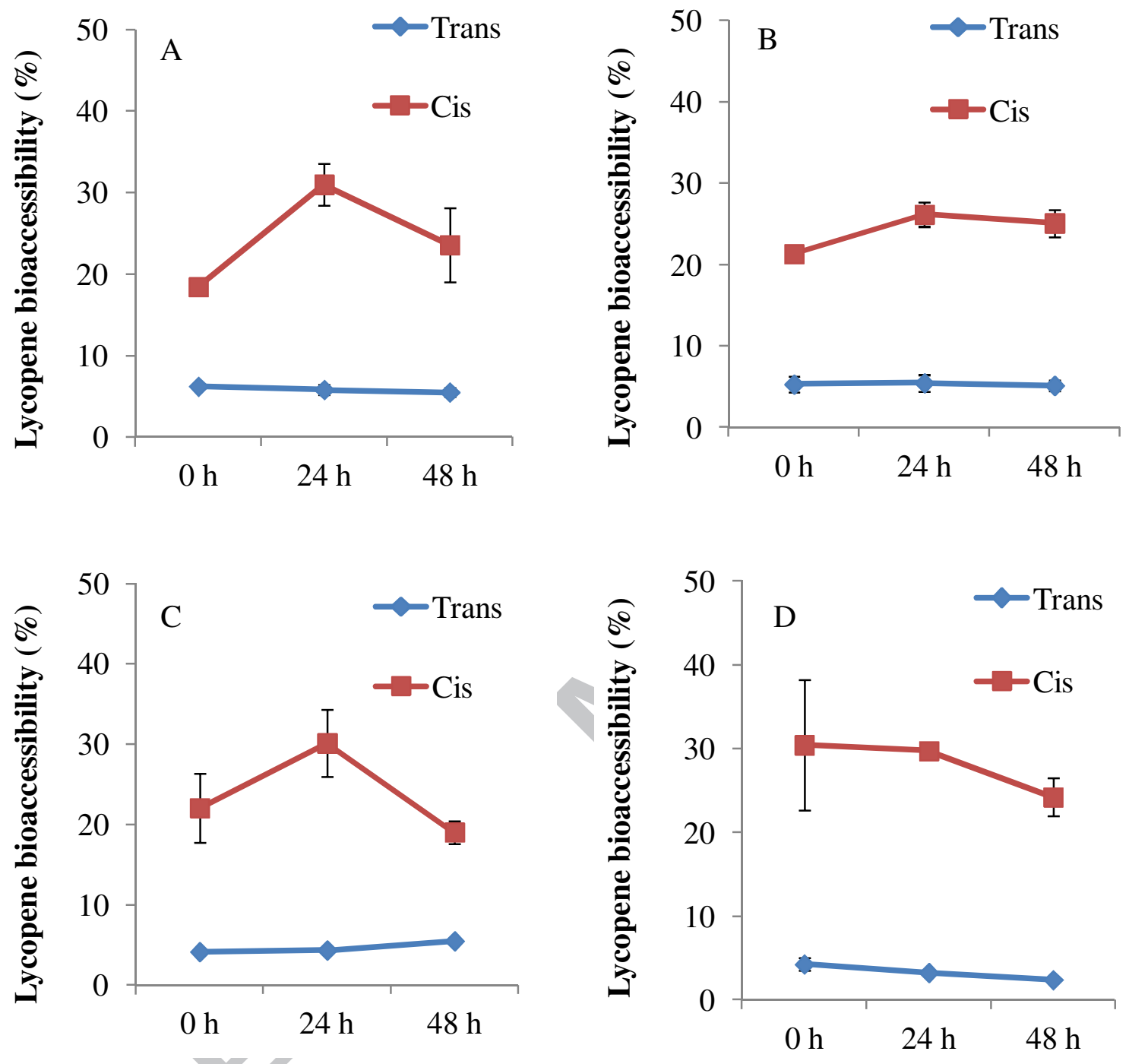

Figure 3. Effect of MIPEF treatment and holding period on cis- and trans-lycopene bioaccessibility of tomato fruits. Fresh tomato (A), $4 \mu \mathrm{s}$ (B), $80 \mu \mathrm{s}(\mathrm{C}), 320 \mu \mathrm{s}$ (D). 


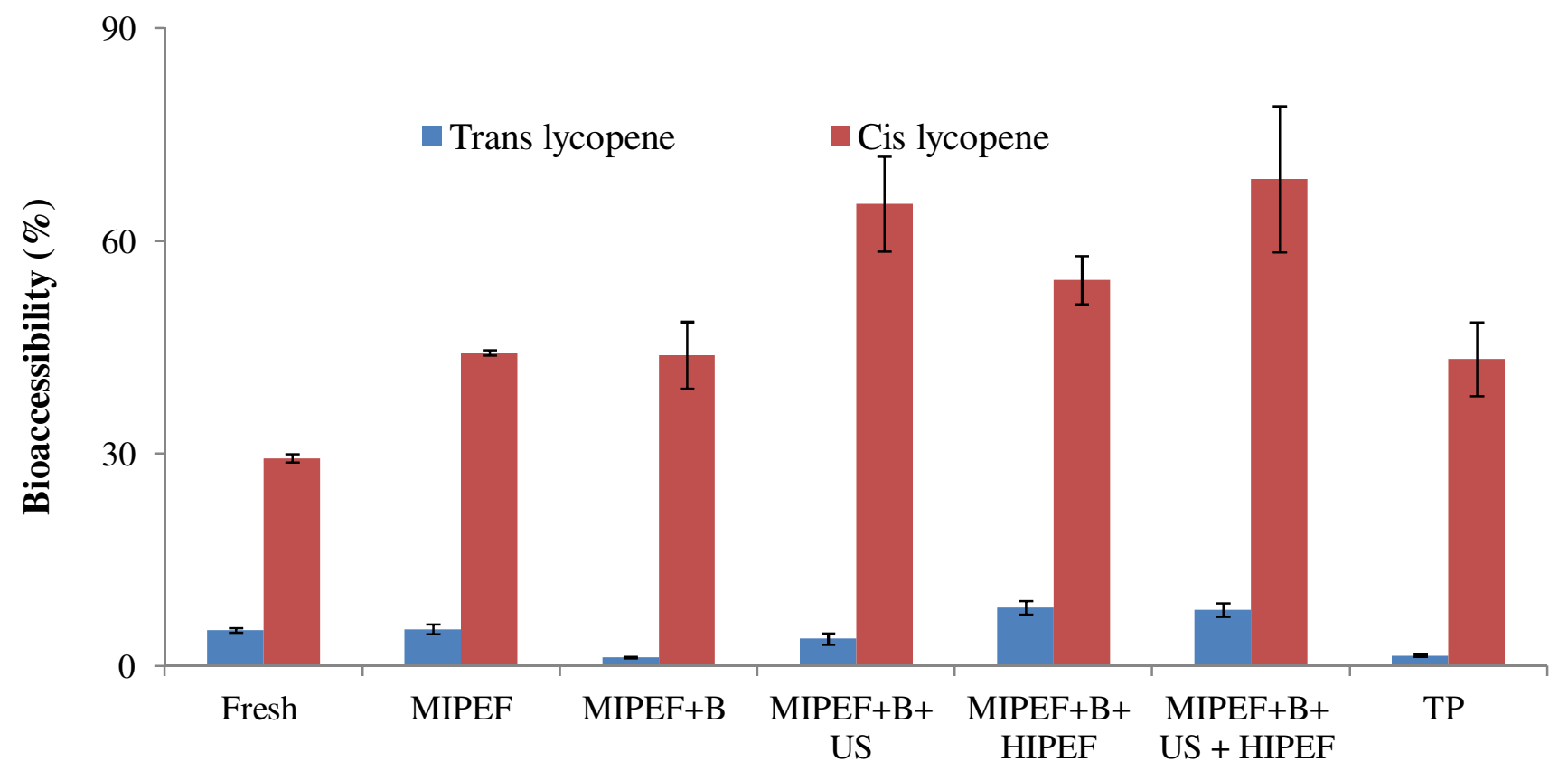

Figure 4. Effect of different processing steps on cis- and trans- lycopene bioaccessibility of tomato juice. 
Table 1. Impact of PEF treatment and holding period on trans- and cis- lycopene concentration of whole tomato $(n=3)$.

\begin{tabular}{|c|c|c|c|c|c|c|c|}
\hline \multirow[t]{2}{*}{ Treatment } & $\begin{array}{l}\text { Holding } \\
\text { period }\end{array}$ & \multicolumn{3}{|c|}{ Amount present in undigested sample } & \multicolumn{3}{|c|}{ Amount present in digesta } \\
\hline & period & $\begin{array}{c}\text { Total } \\
\text { lycopene } \\
(\mu \mathrm{g} / \mathrm{g})\end{array}$ & $\begin{array}{l}\text { All-trans- } \\
\text { lycopene } \\
(\mu \mathrm{g} / \mathrm{g})\end{array}$ & $\begin{array}{c}\text { Cis- } \\
\text { lycopene } \\
(\mu \mathrm{g} / \mathrm{g})\end{array}$ & $\begin{array}{c}\text { Total } \\
\text { lycopene } \\
(\mu \mathrm{g} / \mathrm{g})\end{array}$ & $\begin{array}{l}\text { All-trans- } \\
\text { lycopene } \\
(\mu \mathrm{g} / \mathrm{g})\end{array}$ & $\begin{array}{c}\text { Cis- } \\
\text { lycopene } \\
(\mu \mathrm{g} / \mathrm{g})\end{array}$ \\
\hline Fresh & 0 & $30.68 \pm 0.81 \mathrm{f}$ & $25.98 \pm 0.90 \mathrm{~cd}$ & $4.70 \pm 0.32 c$ & $2.37 \pm 0.21 \mathrm{j}$ & $1.38 \pm 0.20 \mathrm{hi}$ & $1.00 \pm 0.06 \mathrm{~h}$ \\
\hline $4 \mu \mathrm{s}$ & 0 & $32.53 \pm 2.68 \mathrm{e}$ & $28.16 \pm 2.61 \mathrm{~cd}$ & $4.37 \pm 0.13 c$ & $2.54 \pm 0.16 \mathrm{i}$ & $1.74 \pm 0.18 \mathrm{fg}$ & $0.80 \pm 0.03 \mathrm{i}$ \\
\hline $80 \mu \mathrm{s}$ & 0 & $40.80 \pm 3.67 \mathrm{dc}$ & $35.03 \pm 3.21 \mathrm{~b}$ & $5.77 \pm 0.46 b$ & $2.70 \pm 0.20 \mathrm{i}$ & $1.44 \pm 0.09 \mathrm{~h}$ & $1.26 \pm 0.21 \mathrm{~g}$ \\
\hline $320 \mu \mathrm{s}$ & 0 & $57.98 \pm 4.48 \mathrm{a}$ & $50.57 \pm 3.77 \mathrm{a}$ & $7.41 \pm 0.69 a$ & $4.34 \pm 0.60 \mathrm{~g}$ & $2.13 \pm 0.24 \mathrm{e}$ & $2.22 \pm 0.39 \mathrm{~d}$ \\
\hline Fresh & 24 & $29.40 \pm 1.94 \mathrm{f}$ & $24.84 \pm 2.08 \mathrm{~d}$ & $4.55 \pm 0.21 \mathrm{c}$ & $2.53 \pm 0.11 \mathrm{ij}$ & $1.34 \pm 0.13 \mathrm{hi}$ & $1.19 \pm 0.19 \mathrm{~g}$ \\
\hline $4 \mu \mathrm{s}$ & 24 & $34.54 \pm 2.42 \mathrm{e}$ & $29.18 \pm 1.96 \mathrm{~cd}$ & $5.36 \pm 0.47 b$ & $3.33 \pm 0.13 \mathrm{~h}$ & $1.68 \pm 0.10 \mathrm{fg}$ & $1.65 \pm 0.04 \mathrm{e}$ \\
\hline $80 \mu \mathrm{s}$ & 24 & $44.38 \pm 3.51 b c$ & $38.65 \pm 3.30 \mathrm{~b}$ & $5.73 \pm 0.49 b$ & $3.37 \pm 0.17 \mathrm{~h}$ & $1.66 \pm 0.11 \mathrm{~g}$ & $1.71 \pm 0.08 \mathrm{e}$ \\
\hline $320 \mu \mathrm{s}$ & 24 & $45.97 \pm 3.24 b$ & $39.20 \pm 2.72 b$ & $6.77 \pm 0.55 \mathrm{ab}$ & $3.27 \pm 0.22 \mathrm{~h}$ & $1.27 \pm 0.12 \mathrm{i}$ & $2.01 \pm 0.13 \mathrm{~d}$ \\
\hline Fresh & & $35 \pm 2.18 \mathrm{e}$ & $27.58 \pm 2.10 \mathrm{~cd}$ & $4.76 \pm 0.45 c$ & $2.61 \pm 0.16 \mathrm{i}$ & $1.41 \pm 0.07 \mathrm{~h}$ & $1.20 \pm 0.10 \mathrm{~g}$ \\
\hline $4 \mu \mathrm{s}$ & 18 & $38.39 \pm 1.30 \mathrm{~d}$ & $32.76 \pm 1.26 \mathrm{bc}$ & $5.63 \pm 0.33 b$ & $3.11 \pm 0.41 \mathrm{~h}$ & $1.79 \pm 0.22 f$ & $1.32 \pm 0.19 \mathrm{fg}$ \\
\hline 80 & 48 & $45.18 \pm 2.89 \mathrm{bc}$ & $39.69 \pm 2.59 b$ & $6.49 \pm 0.30 \mathrm{a}$ & $3.28 \pm 0.24 \mathrm{~h}$ & $2.05 \pm 0.25 \mathrm{e}$ & $1.23 \pm 0.04 \mathrm{~g}$ \\
\hline $320 \mu s$ & 48 & $42.56 \pm 0.42 c$ & $36.35 \pm 0.31 b$ & $6.21 \pm 0.13 \mathrm{ab}$ & $2.37 \pm 0.26 \mathrm{j}$ & $0.87 \pm 0.11 \mathrm{j}$ & $1.50 \pm 0.17 \mathrm{f}$ \\
\hline
\end{tabular}

Values are means \pm standard deviation. Values within the same column followed by the same letter are not significantly different at $\mathrm{p}<0.05$. 
Table 2. Effect of processing step on changes in trans- and cis-lycopene concentration of tomato juice $(n=3)$ before and after digestion.

\begin{tabular}{|l|ccc|ccc|}
\hline \multirow{2}{*}{ Treatment } & \multicolumn{2}{|c|}{ Amount present in undigested sample } & \multicolumn{2}{|c|}{ Amount present in digesta } \\
\cline { 2 - 8 } & $\begin{array}{c}\text { Total } \\
\text { lycopene }\end{array}$ & $\begin{array}{c}\text { All-trans- } \\
\text { lycopene }\end{array}$ & $\begin{array}{c}\text { Cis- } \\
\text { lycopene } \\
\end{array}$ & $\begin{array}{c}\text { Total } \\
\text { lycopene } \\
(\mu \mathrm{g} / \mathrm{g})\end{array}$ & $\begin{array}{c}\text { All-trans- } \\
\text { lycopene }\end{array}$ & $\begin{array}{c}\text { Cis- } \\
\text { lycopene }\end{array}$ \\
\hline Fresh juice & $29.58 \pm 1.51 \mathrm{~g} / \mathrm{g})$ & $25.90 \pm 1.78 \mathrm{c}$ & $3.68 \pm 0.30 \mathrm{c}$ & $2.38 \pm 0.08 \mathrm{f}$ & $1.30 \pm 0.02 \mathrm{c}$ & $1.08 \pm 0.16 \mathrm{c}$ \\
MIPEF (M) & $32.20 \pm 0.32 \mathrm{~d}$ & $28.32 \pm 0.23 \mathrm{de}$ & $4.88 \pm 0.32 \mathrm{~b}$ & $3.63 \pm 0.07 \mathrm{~d}$ & $1.48 \pm 0.21 \mathrm{c}$ & $2.16 \pm 0.16 \mathrm{~b}$ \\
M + blanching (B) & $41.49 \pm 1.78 \mathrm{~b}$ & $37.64 \pm 1.33 \mathrm{c}$ & $3.86 \pm 0.45 \mathrm{c}$ & $4.14 \pm 0.01 \mathrm{c}$ & $0.46 \pm 0.04 \mathrm{~d}$ & $1.68 \pm 0.04 \mathrm{c}$ \\
M+B+US & $43.43 \pm 3.41 \mathrm{~b}$ & $41.80 \pm 3.52 \mathrm{~b}$ & $1.63 \pm 0.16 \mathrm{e}$ & $2.65 \pm 0.22 \mathrm{e}$ & $1.59 \pm 0.23 \mathrm{c}$ & $1.06 \pm 0.02 \mathrm{~d}$ \\
M+B+HIPEF & $58.02 \pm 1.69 \mathrm{a}$ & $48.75 \pm 1.68 \mathrm{a}$ & $9.27 \pm 0.36 \mathrm{a}$ & $9.05 \pm 0.57 \mathrm{a}$ & $4.01 \pm 0.48 \mathrm{a}$ & $5.04 \pm 0.26 \mathrm{a}$ \\
M+B+US+HIPEF & $37.88 \pm 2.76 \mathrm{c}$ & $35.03 \pm 2.54 \mathrm{c}$ & $2.85 \pm 0.32 \mathrm{~d}$ & $4.69 \pm 0.10 \mathrm{~b}$ & $2.75 \pm 0.15 \mathrm{~b}$ & $1.94 \pm 0.20 \mathrm{bc}$ \\
Thermal processing & $33.84 \pm 1.12 \mathrm{~d}$ & $31.01 \pm 1.41 \mathrm{~d}$ & $2.82 \pm 0.31 \mathrm{~d}$ & $1.67 \pm 0.05 \mathrm{~g}$ & $0.46 \pm 0.04 \mathrm{~d}$ & $1.21 \pm 0.09 \mathrm{~d}$ \\
\hline
\end{tabular}

Values are means \pm standard deviation. Values within each column followed by the same letter are not significantly different at $\mathrm{p}<0.05$. 


\section{HIGHLIGHTS}

- Impact of processing methods on tomato lycopene bioaccessibility studied.

- Pulse electric field treatment enhanced the lycopene bioaccessibility of tomato.

- Blanching \& thermal processing reduced lycopene release during digestion.

- Combined thermal \& non-thermal treatments enhanced lycopene bioaccessibility. 